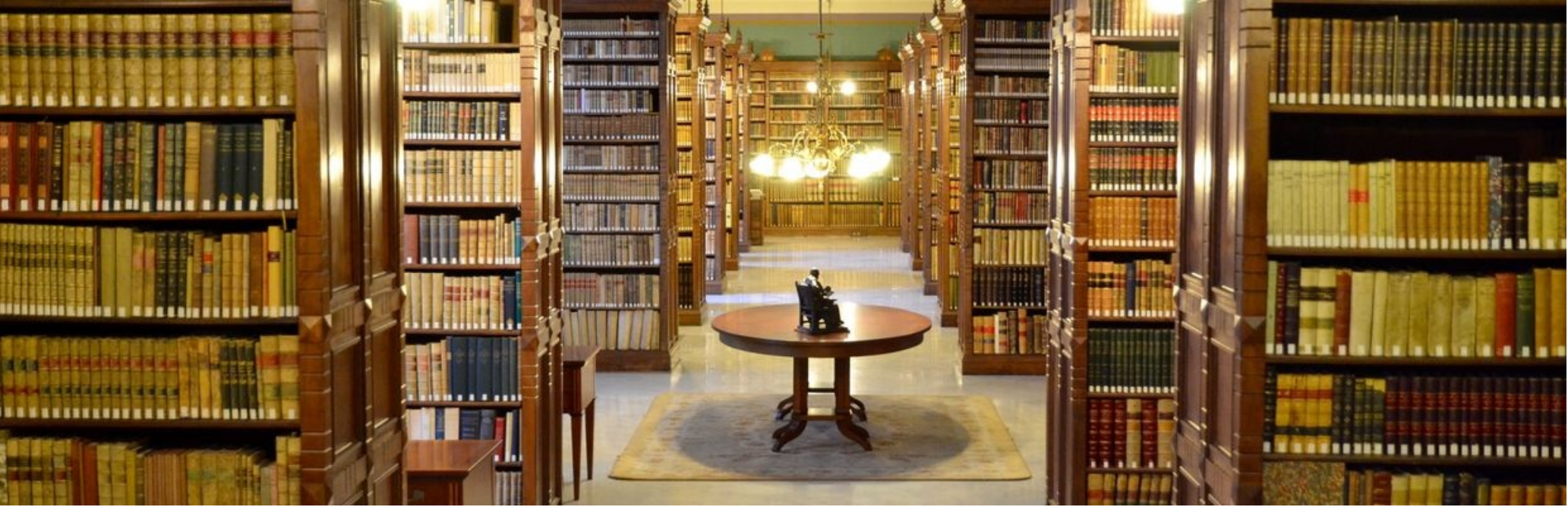

\title{
Editorial Volume 7, Issue 5
}

$\begin{aligned} \text { Authors: } & \text { Stephan Seiler } \\ \text { Submitted: } & \text { 5. November } 2020 \\ \text { Published: } & 8 \text { November } 2020 \\ \text { Volume: } & 7 \\ \text { Issue: } & 6 \\ \text { Affiliation: } & \text { Josha Journal. Freiburg, Germany } \\ \text { Languages: } & \text { English } \\ \text { Keywords: } & \text { Editorial, JOSHA Journal, } 2020 \text { September-November 2nd } \\ \text { Categories: } & \text { News and Views } \\ \text { DOI: } & 10.17160 / \text { josha.7.6.720 }\end{aligned}$

Abstract:

Dear JOSHA readers, In this bi-monthly issue we will present you the 2020 Demetrios Award winners. Five prizes go to young researchers in the categories Bachelor, Master and PHD. In addition, there are many other interesting contributions to discover. Finally we would like to remind you that you can support us with a small donation. http://josha-journal.org/en/donate Visit our social media \#joshajournal and get to know us from the Instagram gallery and the Facebook wall. Remember that you can comment on the articles and also provide your star ranking.

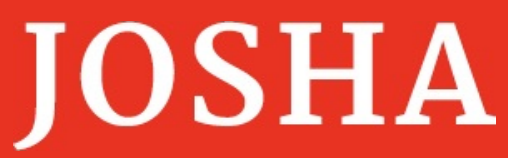

josha.org
Journal of Science,

Humanities and Arts

JOSHA is a service that helps scholars, researchers, and students discover, use, and build upon a wide range of content 


\section{Editorial \\ Volume 7, Issue 5}

\section{Demetrios Prizes 2020}

Waiting is finally over! The International Academy of Sciences, Humanities and Arts (IASHA e.V.) has determined this year's winners of the Demetrios prizes. All applications were of a high standard, the selection was therefore not easy. We are happy to award two prizes in the category Bachelor thesis, two prizes in the category Master thesis and one prize in the category Doctoral thesis.

\section{Bachelor theses}

A Bachelor's Prize is awarded to Chiara Giardi from San Marino for her work "Mapmaking and Storytelling" in the field of Liberal Arts \& Sciences. Giardi wrote her work on the exhibition "Subjective Maps /Disappearances", which was shown at the National Gallery of Iceland in 2013.

Another Bachelor's Prize is awarded to Yenniffer Mena from Colombia for "Latin American Philosophy as an Instrument for Transforming Action of Reality" in the field of Philosophy. In her thesis Mena makes an approach to the historical circumstances of being Latin American.

\section{Master theses}

Gisela Pattarone from Argentina received a Master's Prize in the category Medicine for "Automatic Breast Cancer Cell Classification using deep Convolutional neural Networks". Her work was performed within the IMBS International Master/PHD Program in Biomedical Sciences at the Universities of Buenos Aires and Freiburg im Breisgau.

Christopher Winterhalder from Germany received a Master's Prize in the category Humanities . His thesis "Sport in der Ganztagsschule - Sports in full day Schools" deals with sports and physical activity in school sports at all-day schools since the PISA study in 2001.

\section{Doctor thesis}

A Doctor Prize is awarded to Ana Belén Peñaherrera Pazmiño from Argentina in the field of Engineering for her study "Development of microfluidic Channels". The objective of her thesis was to develop and investigate microfluidic devices to be applied to the culture of eukaryotic cells and the study of fluids in porous media.

Congratulations from the entire JOSHA/IASHA Team and THANKS to ALL participants for their much appreciated contribution! 


\section{Your Donation for JOSHA, the multidisciplinary internet Journal of Sciences, Humanities and Arts}

Once again, we celebrate the mission of JOSHA to offer its library services. As a non-profit organization, IASHA e.V. and the philanthropic BioThera Roland Mertelsmann Foundation have been able to provide scholarships to significantly support the careers of many students, artists, and young scientists from all around the world. Our open-access journal lays out a forum where they can present their achievements. There, you can value their presentations and follow-up on the impact of your donation. Today we are announcing a new button on our website through which you can support us. With your donation you set a sign of philanthropy and help to continue our mission to support the future careers of young gifted people.

Donate

Now we hope you enjoy reading the journal, the Demetrios Prize contributions and look forward to many exciting further articles.

\section{Dr. Stephan Seiler}

Vice President

International Academy of Sciences, Humanities and Arts

Volume 7, Issue 5

Dario Ruarte, Optimization of long-term Breast Cancer Cell Culture using live Imaging in an automated Perfusion System

Yenniffer Mercedes Mena Gamarra, La Filosofía latinoamericana como Instrumento para la Accion Transformadora de la Realidad - Latin American Philosophy as an Instrument for Transforming Action of Reality

Sebastián Vishnopolska, An open book

Britta Ullrich, black \& white

Franziska Buttgereit, Music \& Medicine

Timoteo Marchini, The Tell Tale Heart

Helmut Haussmann, Weltpolitikfähigkeit - The Ability of World Politics

Luis Enrique Silva Vieira, Charles Taylor: Una Aproximación a la Noción de Reconocimento e Identidad Charles Taylor: An Approach to the Notion of Recognition and Identity

Felicitas Holzer, Health Impact Fund

Joachim Frank, The Chrysalis Project 